\title{
PERCEPTION OF INNOVATION IN TOURISM WITH REGARD TO CONTROVERSIAL TYPES OF TRAVEL: A STUDY OF POLISH CONSUMERS
}

\author{
Grzegorz Godlewskia ${ }^{\text {iD }}$ \\ a Adam Mickiewicz University in Poznań, Faculty of Geographical and Geological Sciences, Department of Tourism and Recreation; \\ https://orcid.org/0000-0002-5860-1795; e-mail: grzgod@amu.edu.pl
}

\begin{abstract}
The aim was to determine how tourism innovations, including controversial types of tourism, are perceived by consumers. The hypothesis adopted was that there would be statistically significant correlations between demographic variables, the respondents' perception of innovations and their propensity to engage in non-normative behaviour during tourism trips. The study was conducted using the CAWI surveying technique by means of an online questionnaire $(\mathrm{N}=407)$. The respondents had noticed significant changes in the tourism industry and the majority were in favour of those innovations. These mainly related to the development of tourist service infrastructure. The study found a statistically significant difference between male and female respondents with more males in favour of introducing controversial tourism offers to the market. Male respondents were also more likely to engage in deviant behaviour.
\end{abstract}

\section{KEYWORDS}

consumer behaviour, innovations in tourism, controversy in tourism

\section{ARTICLE INFORMATION DETAILS}

Received:

27 January 2021

Accepted:

11 May 2021

Published:

25 June 2021

\section{INTRODUCTION}

Tourism, an industry which is developing rapidly at both regional and national levels, is becoming a desirable area of activity to allow local potential to be fulfilled. Research has shown that there is a positive relationship between long-term economic growth and the development of tourism (Samimi, Sadeghi, Sadeghi, 2011). Thanks to a relatively strong global economy, a growing middle class in emerging countries, technological developments, new business models, the affordability of travel and visa facilitation, international tourism grew by $5 \%$ in 2018 compared to 2017, reaching 1.4 billion trips (UNWTO, 2019). However, it should be noted that the tourism industry is vulnerable to threats, mainly from political instability in many regions of the world, terrorism, conflicts and disease, a notable example being the current pandemic and the administrative decisions of authorities that restrict, if not prevent, tourism. Such negative impacts lead to a significant loss of income and jobs and, in extreme cases, may eliminate tourism altogether. Its subsequent restoration would entail a significant investment in terms of time and money (Scott, Laws, Prideaux, 2013; Teitler-Regev, Shahrabani, Goziker, 2013).

Overtourism, too, has negative consequences, especially in terms of the degradation of the environment and problems for the social life of local residents. These negative developments often result in restrictions imposed on travel to tourist destinations as well as amendments to legal regulations that inhibit tourism. Given an increase in travel, this may result in customers searching for other, as yet "undiscovered", equivalent or substitute destinations. 
One factor that may slow down those negative processes in the tourism sector is the creation of innovative solutions which are not necessarily limited to conventional, uncontroversial products or types of tourism.

The aim of the article is to bridge a research and literature gap regarding the analysis of controversies in the Polish tourism market in relation to innovations.

\section{INNOVATION IN THE TOURISM SECTOR: SIGNIFICANCE AND SCOPE}

Innovation is perceived as a driver of modern economies and a critical factor for economic growth. In micro-economic terms, it is seen as an opportunity for companies to strengthen their offer and position in the market. Over recent years, interest in innovation has increased significantly in many sectors, including the tourism industry whose complex, multidimensional nature facilitates the creation of economic reality into all the components of the tourism market. Hjalager (2010) lists several types of innovation associated with tourism relating to products, processes, management, marketing and institutions, with the service sector combining these different categories of innovation.

The constant evolution of markets forces companies to systematically develop and implement innovations, defined as the use of a new or substantially improved product or process, a new marketing method or a new organisational method in business practice, workplace organisation and relations with the environment (OECD, Eurostat, 2005). According to Schumpeter (1960), innovation involves putting a new solution into practice (however, it should be noted that Schumpeter focused mainly on technological innovation and its economic impact). Innovation is also understood as a continuum of technological and organisational change covering, on the one hand, simple modifications to existing products, processes and practices (which may be new to a company, but not necessarily new to the industry) and, on the other hand, fundamentally new products and processes (both to the industry and to a company). The development of such innovations involves a wide range of scientific, technological, organisational, financial and commercial activity (Porter, 1990). Innovations are implemented in all economic sectors. For instance, tourism businesses introduce innovations by developing a new tourism offer or improving existing ones, and using new technologies in distribution and/or promotion to implement innovative solutions in terms of business management, forms of organisation and rules for cooperation. One other interesting area of innovation is the use of unique architecture, facility design, location of an enterprise and development of the surrounding area. The changes caused by innovations can be radical (pioneering) and/or imitative (adaptation, modification) (Dolińska, 2010).

A high level of innovation translates into a competitive advantage in the market. The determinants of the diffusion of innovation in tourism can be divided into external and internal factors. External factors include activity in the tourism economy, the development of tourism research, the following of economic trends, state tourism innovation policies, the level of competition within the market, observation and analysis of needs, fiscal and tax instruments for promoting innovation, and institutional infrastructure supporting innovation. In turn, internal factors include the commercial viability of innovations for tourism businesses, their creative mentality and intellectual capital, the minimum investment necessary to implement innovations, the complexity of the innovation process and accidental impacts (Januszewska, 2008).

Given the great importance of tourists' experiences and the strong link between tourism and space, innovative activity in the area discussed has unique features. The diffusion of new solutions takes place at a faster rate in tourism compared with other economic sectors. Intellectual property is usually of minor importance for tourism businesses as research and development work, which has a significant impact on business, is undertaken and implemented outside the tourism sector (Łaźniewska, 2012).

According to Pine and Gilmore (1998), companies may create offerings enriched with experiences which are perceived as a new source of customer value and are the basis for customer satisfaction. This was also stressed by Urry (1990) and MacCannell $(1973,1976)$ in their publications.

The factors behind the creation of experiences include the presence, knowledge and sensitivity of an individual as well as the presence of raw materials, goods and/or services. In an economy in which experiences are considered tradable commodities, customers purchase other products provided that they offer them the experiences they expect - usually positive ones (Marciszewska, 2010).

The key ways to intensify experiences include (Stasiak, 2013):

- transforming the tourist infrastructure into unique attractions,

- 'wrapping' experiences and emotions around traditional packages of services,

- creating augmented reality experiences using new technologies that make tourist space more attractive,

- discovering new tourist spaces offering unique and extreme experiences,

- developing new forms of tourism which develop the skills, creativity and personality of tourists. 
As the experiences and emotions of tourists are considered tradable commodities, tourists expect, for whatever demands they voice, a professional and comprehensive tourist offer, and this includes those needs that raise ethical questions.

\section{CONTROVERSIAL TYPES OF TOURISM} IN THE CONTEXT OF DEVIANT TOURIST BEHAVIOUR

Deviant tourist behaviour (DTB) is defined in the literature as tourist behaviour which causes various types of damage (social, cultural, environmental and economic) to tourist-receiving areas. Such behaviour, which is quite common, includes violence (Hughes et al., 2008; Kerr, de Kock, 2002), destruction of native flora (e.g. plants, corals) by taking it home as a souvenir (Weaver, 2006), lack of respect for cultural traditions (Bhati, Pearce, 2016) and putting illegal graffiti on buildings (Thirumaran, 2013). The behaviour is damaging for tourist assets, but it can also hinder consumption and negatively impact the tourist experiences of other visitors, causing tangible losses to tourism businesses. Deviant tourist behaviour includes behaviour that may be considered liminal, at the edge of social legitimacy and even illegal (Ryan, Kinder, 1996). At the same time, a growing number of tourists are interested in 'civilised' activities and it is those tourists who may provide a major contribution to a reduction of the impact of dysfunctions on touristreceiving areas (Juvan, Dolnicar, 2016).

Ongoing research on deviant tourist behaviour mainly focuses on emphasising and exploring its patterns and causes as well as possible corrective measures (Juvan, Dolnicar, 2016). Based on their sociological study, Uriely, Ram and Ayala (2011) even suggest that tourism activity as a whole encourages deviant tourist behaviour in a natural, involuntary way. Such behaviour will be reinforced by marketing pressures, which stimulate the involvement of market relations.

A study by $\mathrm{Li}$ (2015) on the causes of deviant behaviour in individuals and groups showed that the main causal factors behind the behaviour are the inappropriate habits of tourists. However, the available literature does not provide solutions as to how to deal with the problem. Therefore, models should be developed that can help adopt an optimum strategy for action to change the attitudes and needs of tourists

Stebbins (1996) refers to the deviant behaviour of consumers which is tolerable to an extent (e.g. gambling, alcohol abuse, use of soft drugs, pornography viewing, visiting nudist beaches) as 'deviant leisure'. Where these activities are undertaken during a temporary tourist visit, they are treated as deviant tourism (Ryan, Kinder, 1996; Uriely, Belhassen, 2005, 2006). Tourism may be considered a unique realm, as it is associated with an escape from the routine of everyday life. Some authors try to explain the deviant behaviour of tourists by comparing tourism to an alternative domain of life different from the everyday and in which the suspension of social norms and values is possible, tolerated or even necessary (Goffman, 1963, 1967; Shields, 1992; Turner, Ash, 1975). In line with this approach, Wang (2000) ambiguously referred to tourism as 'Eros-modernity' where an individual is allowed to engage in socially irrational behaviour, as in the theory of deviant behaviour by Hirschi (1969). Turner and Ash (1975) even suggest that temporary distance from their usual environment allows tourists to suspend the norms and values governing their everyday lives. Similarly, Shields (1992) associated tourist spaces, such as beaches, with the suspension of social constraints, mainly due to anonymity and weakened social control.

One of the key models of the systemic concepts used to explain it, is the sociocultural model of tourism of Jafar Jafari. The model assumes that there are two opposing systems in the global macro-system - the tourist-sending system, which is part of the daily life of a tourist and is based on the definitional 'usual environment'; and the tourist-receiving system, which is separated from everyday life, comprising tourist-receiving areas where the tourist can satisfy needs and grasp the opportunity for mental and physical regeneration through recreation. It is within the latter system that unfamiliar "foreign bodies" (tourists from different places), characterised by different behaviours and cultures, come into contact with one another leading to uncontrolled interpersonal and intercultural interactions. According to Jafari (1987), these may result in changes to tourist-receiving systems posing a threat to their identity.

This area of social life, which legitimises and even encourages non-normative behaviour, may be precisely explained by Goffman's theory of social interaction. This theory states that when interacting with others, people want, in fact, to make a good impression on the 'public', as they believe it will be beneficial for them. This allows an individual to show others those aspects of their personality that they want noticed and remembered. According to the theoretical parameters developed by Goffman $(1963,1967)$, each person strives to build a desirable public image for him or herself. By participating in different forms of entertainment and using tourism-related facilities (e.g. discos, resorts, casinos, amusement parks) - so-called "backspaces" or "action spaces" - people can experience what they cannot have in everyday life.

The literature on deviant tourist behaviour seems to be based on an assumption that it is relatively strongly correlated with the routinisation of everyday life, but this is not always in line with postmodern conceptualisations of tourism (Lash, Urry, 1994; Munt, 
1994; Uriely, 2005; Urry, 1990) and analyses by other authors (Larsen, 2008; Larsen, Urry, Axhausen, 2007; Uriely, 2010). Modern theories underline the time and space factors that legitimise or even encourage a temporary suspension of the norms of everyday life.

The term 'tourist awareness' includes reference to a tourist's knowledge and understanding of unethical and deviant behaviour, its definition and essence as well as possible penalties and the inconvenience associated with particular activities. The higher the awareness, the greater the likelihood that the behaviour of tourists will be guided by positive habits and norms.

Different types of tourism are associated with different types of deviant behaviour. The most controversial types include sex tourism, drug tourism, some forms of medical tourism (pharma-tourism, abortion tourism and euthanasia tourism), LGBTQ tourism, slum/poverty tourism, disaster tourism, extreme tourism and thanatourism (Panasiuk, 2015). Each of those types may provoke the behaviour referred to above and, at the same time, be a source of innovative change in businesses.

\section{AIMS, MATERIAL AND METHODS, AND LIMITATIONS OF THE RESEARCH}

The paper addresses the issue of innovation and controversies in the Polish tourism market. The analyses presented are part of a study titled "The role of tourism in the contemporary consumption model: controversies in the Polish tourism sector" carried out by the author between 2015 and 2018, which used a wide range of research methods and techniques (desk research, 'mystery shopping', individual indepth interviews, CAWI, expert panel) enabling an in-depth analysis, including one of real demand, and the identification of factors affecting the consumption of controversial tourism services. For obvious reasons, it was not possible to present all the results in this article due to length constraints.

The main aim was to determine how consumers perceive tourism innovations, including controversies, which are attracting an increasing interest from consumers. The author also aimed to answer the question of what innovations in the tourism sector

Table 1. Independent variables/features characterising the respondents

\begin{tabular}{|c|c|c|}
\hline Place of residence & Number of answers & Percent \\
\hline Metropolitan area (over 500000 inhabitants) & 52 & 12.8 \\
\hline Large urban area (between 100 and 500000 inhabitants) & 74 & 18.2 \\
\hline Medium-sized urban area (between 20 and 99000 inhabitants) & 80 & 19.7 \\
\hline Small urban area (up to 20000 inhabitants) & 52 & 12.8 \\
\hline Rural area & 149 & 36.5 \\
\hline Total & 407 & 100.0 \\
\hline Education (highest level completed) & Number of answers & Percent \\
\hline Primary/lower-secondary education & 9 & 2.2 \\
\hline Basic vocational education & 36 & 8.9 \\
\hline Secondary education & 131 & 32.2 \\
\hline Post-secondary education & 64 & 15.7 \\
\hline Bachelor degree & 34 & 8.4 \\
\hline Master's degree & 133 & 32.6 \\
\hline Total & 407 & 100.0 \\
\hline Sex & Number of answers & Percent \\
\hline Female & 206 & 50.6 \\
\hline Male & 201 & 49.4 \\
\hline Total & 407 & 100.0 \\
\hline Age (years) & Number of answers & Percent \\
\hline $18-24$ & 53 & 13.0 \\
\hline $25-34$ & 81 & 19.9 \\
\hline $35-44$ & 65 & 15.9 \\
\hline $45-54$ & 79 & 19.4 \\
\hline 55 and over & 129 & 31.8 \\
\hline Total & 407 & 100.0 \\
\hline
\end{tabular}

Source: author. 
have been noticed by Polish consumers, including those types of tourism that are debated and contentious, and are considered controversial.

According to the hypothesis adopted there would be a statistically significant correlation between dependent and independent variables (demographic characteristics of respondents), with respect to their perception of innovation, and controversial types of tourism, especially in terms of determining whether consumers who live in large cities, are better educated (and thus often earning higher income), and are not in a formal relationship, are more likely to engage in deviant behaviour and controversial types of tourism.

When designing this part of the research, the author ensured that the sample was as representative as possible (essential for quantitative analyses) and that the activities to be carried out and their conditions were standardised. Efforts were also made to minimise the risk of classic measurement errors (Sztabiński, Żmijewska-Jędrzejczyk, 2012).

When investigating innovations in the tourism sector and its controversial forms, the author was aware that the issues addressed are potentially sensitive. The study was conducted using the CAWI (Computer-Assisted Web Interview) method by means of an interview questionnaire (to be self-administered) provided to 407 respondents over the internet. Analyses were carried out on a nationwide sample of the Polish population aged $\geq 18$, with age, sex, education and the size of their places of residence as independent variables (Table 1).

One basic limitation of the research method used is the geographically diversified and, until recently, the low level of access by households to the internet (socalled internet penetration) and the resulting coverage error. Another limitation was that the researcher had no control over who actually completes the questionnaire. Despite its structured nature, e-mail contact with the respondents enabled a relatively free exchange of information between the researcher and the respondents.

\section{RESULTS}

The vast majority of the respondents $(80.5 \%)$ stated that Poland has a strong potential for the development of innovative tourism offers ${ }^{1}$. Slightly over $5 \%$ of the respondents stated that Poland does not have potential for the development of innovative tourism offers while almost three times more (14\%) were unable to give a clear answer and selected "I don't have an opinion".

According to the respondents, consumer needs are the most crucial factor for the development of innovative tourism offers in Poland (65.4\%). Other factors were cited less frequently. The factors that were considered important include competition on the tourism market (47.4\%), the creativity of managers $(44.2 \%)$ and the ability to obtain external sources of finance for innovative ventures (38.3\%).

The largest proportion of respondents were in favour of innovation, subject however to certain limitations (42\%) (relating, for instance, to the accessibility and promotion of controversial tourism offers), whereas $31 \%$ were in favour of all innovation in the tourism sector. One-fourth $(25 \%)$ had no opinion on the subject and only $2.5 \%$ were against innovation. The largest proportion had noticed offers relating to the development of the tourist infrastructure (providing services to travellers - accommodation, catering facilities, tourist information, travel agents, etc.) (42.5\%). Only some declared that they had noticed innovations related to controversial offers $(15 \%)$. This means that such tourism products are not primarily perceived as particularly innovative.

A more detailed analysis was carried out based on closed questions. The respondents could choose from a list of several answers pertaining to accessibility to natural and cultural assets, development of the tourist infrastructure, new offers for visitors in tourist-receiving regions and controversial products. The respondents could also declare that they had not noticed any innovations in tourism.

When analysing the relationship between independent variables and the perception of innovations in the Polish tourism sector, no statistically significant correlations were found in most cases. However, there were certain exceptions.

Statistically significant correlations were found when analysing the responses of the respondents (divided by sex) concerning new tourism offers (e.g. tours to previously lesser-known regions and using available attractions). The number of female respondents in favour of such innovations was greater than that of male. Statistically significant differences were also found for the respondents' perception of controversial innovations. Statistically significantly more men than women were in favour of the introduction of such tourism offers into the market. Significant correlations were also found for the age of the respondents and their place of residence. Moreover, statistically significant differences were found when analysing the distribution by education of those respondents who stated that they had not noticed any innovations in the Polish tourism market (Table 2).

The opinions of the respondents (those in favour of all innovation, those in favour of innovation, subject to certain limitations, and those against innovation), as regards Polish tourism products involving controversial tourism offers, also varied. The differences were statistically significant, in particular in the case of a comparison of the respondents who were in favour of all innovation and those who had no opinion on the subject (Table 3). 
Table 2. Categories of innovation in the Polish tourism product noticed by respondents over the past five years (statistically significant correlations)

\begin{tabular}{|c|c|c|c|c|c|}
\hline \multirow{3}{*}{ Sex of the respondents } & \multicolumn{4}{|c|}{$\begin{array}{c}\text { Innovations in the Polish tourism product relating to new regions } \\
\text { and the tourist attractions they offer }\end{array}$} & \multirow{3}{*}{$\begin{array}{l}\text { Pearson's } \\
\text { chi-squared test }\end{array}$} \\
\hline & \multicolumn{2}{|c|}{ No } & \multicolumn{2}{|c|}{ Yes } & \\
\hline & $\begin{array}{l}\text { Number } \\
\text { of answers }\end{array}$ & Percent & $\begin{array}{l}\text { Number } \\
\text { of answers }\end{array}$ & Percent & \\
\hline Female & 118 & 57.28 & 88 & 42.72 & \multirow{2}{*}{$\begin{array}{c}d f=1 \\
p=.03041\end{array}$} \\
\hline Male & 136 & 67.66 & 65 & 32.34 & \\
\hline Sex of the respondents & \multicolumn{4}{|c|}{$\begin{array}{l}\text { Innovations in the Polish tourism product relating } \\
\text { to the marketing of controversial tourism offers }\end{array}$} & $\begin{array}{c}\text { Pearson's } \\
\text { chi-squared test }\end{array}$ \\
\hline Female & 184 & 89.32 & 22 & 10.68 & \multirow{2}{*}{$\begin{array}{c}d f=1 \\
p=.01322\end{array}$} \\
\hline Male & 162 & 80.60 & 39 & 19.40 & \\
\hline Age of the respondents & \multicolumn{4}{|c|}{$\begin{array}{l}\text { Innovations in the Polish tourism product relating } \\
\text { to the marketing of controversial tourism offers }\end{array}$} & $\begin{array}{c}\text { Pearson's } \\
\text { chi-squared test }\end{array}$ \\
\hline $18-24$ & 42 & 79.25 & 11 & 20.75 & \multirow{5}{*}{$\begin{array}{c}d f=4 \\
p=.00062\end{array}$} \\
\hline $25-34$ & 58 & 71.60 & 23 & 28.40 & \\
\hline $35-44$ & 56 & 86.15 & 9 & 13.85 & \\
\hline $45-54$ & 70 & 88.61 & 9 & 11.39 & \\
\hline 55 and over & 120 & 93.02 & 9 & 6.98 & \\
\hline Place of residence & \multicolumn{4}{|c|}{$\begin{array}{c}\text { Innovations in the Polish tourism product relating to new regions } \\
\text { and the tourist attractions they offer }\end{array}$} & $\begin{array}{c}\text { Pearson's } \\
\text { chi-squared test }\end{array}$ \\
\hline Rural area & 103 & 69.13 & 46 & 30.87 & \multirow{5}{*}{$\begin{array}{c}d f=4 \\
p=.03044\end{array}$} \\
\hline Small urban area & 23 & 44.23 & 29 & 55.77 & \\
\hline Medium-sized urban area & 47 & 58.75 & 33 & 41.25 & \\
\hline Large urban area & 47 & 63.51 & 27 & 36.49 & \\
\hline Metropolitan area & 34 & 65.38 & 18 & 34.62 & \\
\hline Place of residence & \multicolumn{4}{|c|}{$\begin{array}{c}\text { Innovations in the Polish tourism product involving the marketing } \\
\text { of controversial tourism offers }\end{array}$} & $\begin{array}{l}\text { Pearson's } \\
\text { chi-squared test }\end{array}$ \\
\hline Rural area & 130 & 87.25 & 19 & 12.75 & \multirow{5}{*}{$\begin{array}{c}d f=4 \\
p=.01428\end{array}$} \\
\hline Small urban area & 39 & 75.00 & 13 & 25.00 & \\
\hline Medium-sized urban area & 65 & 81.25 & 15 & 18.75 & \\
\hline Large urban area & 70 & 94.59 & 4 & 5.41 & \\
\hline Metropolitan area & 42 & 80.77 & 10 & 19.23 & \\
\hline Education & \multicolumn{4}{|c|}{$\begin{array}{l}\text { Innovations in the Polish tourism product relating } \\
\text { to the development of tourist infrastructure }\end{array}$} & $\begin{array}{c}\text { Pearson's } \\
\text { chi-squared test }\end{array}$ \\
\hline Primary, lower-secondary education & 7 & 77.78 & 2 & 22.22 & \multirow{6}{*}{$\begin{array}{c}d f=5 \\
p=.02295\end{array}$} \\
\hline Basic vocational education & 28 & 77.78 & 8 & 22.22 & \\
\hline Secondary education & 78 & 59.54 & 53 & 40.46 & \\
\hline Post-secondary education & 31 & 48.44 & 33 & 51.56 & \\
\hline Bachelor degree & 15 & 44.12 & 19 & 55.88 & \\
\hline Master's degree & 75 & 56.39 & 58 & 43.61 & \\
\hline Education & \multicolumn{4}{|c|}{ I have not noticed any innovations } & $\begin{array}{c}\text { Pearson's } \\
\text { chi-squared test }\end{array}$ \\
\hline Primary, lower-secondary education & 3 & 33.33 & 6 & 66.67 & \multirow{6}{*}{$\begin{array}{c}d f=5 \\
p=.0038\end{array}$} \\
\hline Basic vocational education & 22 & 61.11 & 14 & 38.89 & \\
\hline Secondary education & 94 & 71.76 & 37 & 28.24 & \\
\hline Post-secondary education & 45 & 70.31 & 19 & 29.69 & \\
\hline Bachelor degree & 298 & 5.29 & 5 & 14.71 & \\
\hline Master's degree & 109 & 81.95 & 24 & 18.05 & \\
\hline
\end{tabular}

Source: author. 
Table 3. Respondents' perception of innovations and controversies in the tourism sector (statistically significant correlations)

\begin{tabular}{|c|c|c|c|c|c|}
\hline \multirow{3}{*}{ Respondents' answers } & \multicolumn{4}{|c|}{$\begin{array}{l}\text { Innovations in the Polish tourism product involving } \\
\text { the marketing of controversial tourism offers }\end{array}$} & \multirow{3}{*}{$\begin{array}{l}\text { Pearson's } \\
\text { chi-squared } \\
\text { test }\end{array}$} \\
\hline & \multicolumn{2}{|c|}{ No } & \multicolumn{2}{|c|}{ Yes } & \\
\hline & $\begin{array}{l}\text { Number } \\
\text { of answers }\end{array}$ & Percent & $\begin{array}{l}\text { Number } \\
\text { of answers }\end{array}$ & Percent & \\
\hline \multicolumn{6}{|c|}{ taking into account all the answers } \\
\hline $\begin{array}{l}\text { Respondents who are in favour } \\
\text { of all innovation }\end{array}$ & 98 & 77.78 & 28 & 22.22 & \multirow{4}{*}{$\begin{array}{c}d f=3 \\
p=.00086\end{array}$} \\
\hline $\begin{array}{l}\text { Respondents who are in favour } \\
\text { of innovation, subject to certain } \\
\text { limitations }\end{array}$ & 144 & 84.71 & 26 & 15.29 & \\
\hline Respondents who are against innovation & 7 & 70.00 & 3 & 30.00 & \\
\hline $\begin{array}{l}\text { Respondents who have no opinion } \\
\text { on innovation }\end{array}$ & 97 & 96.04 & 4 & 3.96 & \\
\hline \multicolumn{6}{|c|}{ taking into account the greatest statistical variation between the answers } \\
\hline $\begin{array}{l}\text { Respondents who are in favour } \\
\text { of all innovation }\end{array}$ & 98 & 77.78 & 28 & 22.22 & \multirow{2}{*}{$\begin{array}{c}d f=1 \\
p=.00009\end{array}$} \\
\hline $\begin{array}{l}\text { Respondents who have no opinion } \\
\text { on innovation }\end{array}$ & 97 & 96.04 & 4 & 3.96 & \\
\hline
\end{tabular}

Source: author.

It was found that respondents who were in favour of all innovations in tourism were statistically significantly more likely to believe that the offering of controversial tourism products is acceptable as compared with those who had no opinion on innovation.

\section{CONCLUSIONS}

Tourism is a dynamic global phenomenon and an agent of change which heralds controversies in the sector. The evolution of the tourism industry has various dysfunctional social, cultural and technical consequences. In order to obtain a complete picture of those implications, critical analyses of the accompanying contexts, causes and effects are needed. A lack of understanding of the roots of controversies in tourism may result in systemic failure to meet the expectations of the main stakeholders - investors and consumers. The situation is complicated by a variety of views on controversies as well as conflicts both within the tourism sector (endogenous controversies) and in external multidimensional contexts (exogenous controversies) (Moufakkir, Burns, 2012).

Discussion of findings based on both Polish and foreign literature seems to be limited due to a shortage of analyses treating controversial tourism and its products as innovations. However, this context is increasingly discussed in public discourse (Godlewski, 2019; Panasiuk, 2015, 2018; Stasiak, 2015) and includes the development and marketing of innovative products and services in the tourism sector. According to Maráková and Medvedová (2016), the development and marketing of such products and services is currently one of the most frequently studied issues as regards tourism. Increased domestic and international competition and saturation of the market provide an incentive to implement innovations (Pechlaner, Fischer, Hamman, 2006; Weiermair, 2004). The creative use of production factors and customer orientation are a prerequisite for the development of innovative tourism offers, which is of relevance for all stakeholders in the market (in functional and structural terms). Product and service innovations are usually noticed by consumers and, in that context, they may be perceived as pioneering and associated with a given company. From the perspective of customers, those factors affect their purchasing behaviour (Maráková, Medvedová, 2016), which is all the more important since the 'massification' of tourism entails a specific homogeneity of behaviour and imitation of recurrent traits, including the seeking of hedonism, amusement, relaxation, escape from everyday life, prestige, satisfaction of curiosity and physical pleasure (Fodness, 1994; Jang, Cai, 2002; Park, Yoon, 2009; Pearce, Lee, 2005), which are also characteristic of controversial forms of tourism.

The findings from the study provide an answer to the research hypothesis put forward in the present paper and yield the following conclusions:

1. The respondents declared that they had noticed significant changes in the tourism industry and the majority of them are in favour of such innovations. However, they believe that the innovations should be subject to certain limitations - it can be concluded 
that these relate to controversial areas of the tourism market.

2. Significant differences were found within the group of respondents in the case of certain variables, which suggests that perceptions of innovations and the potential introduction of controversial tourist services into the market based on innovations are no longer unusual.

3. The limitations indicated by the respondents regarding innovation in the tourism market confirm that it is worth aiming at a model of informed tourists who recognise and understand the values of the places they visit, who are empathetic and actively seek experiences, especially those which are noninvasive in areas with high tourist potential.

4. While in practice the behaviour of tourists at the places they visit varies, it should be noted that some tourist destinations are conducive to deviant behaviour. Examples of such places are large urban centres, which are characterised by anonymity and a 'loose' atmosphere, as well as destinations where tourism carrying capacity and absorptive capacity have been exceeded.

Do Poles approve of controversial deviant tourism offers and treat them as innovative? The study has shown that it is too early to definitively confirm that this is the case. However, the buyers' market must be monitored on an ongoing basis. Moreover, it must be borne in mind that given the changing behaviour of consumers, more strongly emphasised needs, a lack of hesitation in expressing them and even a certain shamelessness and, at the same time, the search for new target markets by producers in the tourism sector (who often offer shocking, exceptional products), controversial forms of tourism must be treated as part of the tourism economy.

The analyses presented in this paper do not exhaust the ways of interpreting market phenomena related to perceiving controversies in the tourism sector as innovation. Therefore, in-depth studies are needed on these issues, including those relating to the supply side of the market.

\section{ENDNOTE}

\footnotetext{
${ }^{1}$ Respondents could choose from the following set of answers: innovation - a) related to accessibility to natural assets (national parks, landscape parks, nature reserves); b) related to accessibility to cultural assets (e.g. museums, galleries, cemeteries, folk art); c) related to the development of tourist infrastructure (to provide services for travellers - accommodation, catering, tourist information, travel agents, etc.); d) related to new tourism offers (e.g. tours to previously lesser-known regions, using available attractions, market controversies); e) related to controversial offers; f) other (what kind?); g) I have not noticed any in novations.
}

\section{REFERENCES}

Bhati, A., Pearce, P. (2016). Vandalism and tourism settings: An integrative review. Tourism Management, 57, 91-105. https:// doi.org/10.1016/j.tourman.2016.05.005

Dolińska, M. (2010). Innowacje w gospodarce opartej na wiedzy. Warsaw: Polskie Wydawnictwo Ekonomiczne.

Fodness, D. (1994). Measuring tourist motivation. Annals of Tourism Research, 21 (3), 555-581.https://doi.org/10.1016/0160-7383(94)90120-1

Godlewski, G. (ed.) (2019). Laboratorium doświadczeń turystycznych. Kontrowersje i problemy wokót wspótczesnej gospodarki turystycznej. Biała Podlaska: Akademia Wychowania Fizycznego Józefa Piłsudskiego w Warszawie. Zamiejscowy Wydział Wychowania Fizycznego w Białej Podlaskiej.

Goffman, E. (1963). Stigma: Notes on the management of spoiled identity. Englewood Cliffs: Prentice-Hall.

Goffman, E. (1967). Interaction ritual: Essay on face-to-face behavior. New York: Anchor Books.

Hirschi, T. (1969). Causes of delinquency. Berkeley: University of California Press.

Hjalager, A.-M. (2010). A review of innovation in hospitality and tourism. Tourism Management, 31 (1), 1-12. https://doi. org/10.1016/j.tourman.2009.08.012

Hughes, K., Bellis, M.A., Calafat, A., Juan, M., Schnitzer, S., Anderson, Z. (2008). Predictors of violence in young tourists: A comparative study of British, German and Spanish holidaymakers. European Journal of Public Health, 18 (6), 569-574. https://doi.org/10.1093/eurpub/ckn080

Jafari, J. (1987). System turystyki. Społeczno-kulturowe modele do zastosowań teoretycznych. Problemy Turystyki, 3, 7-19.

Jang, S., Cai, L. (2002). Travel motivations and destination choice: A study of British outbound market. Journal of Travel and Tourism Marketing, 13 (3), 111-133. https://doi.org/10.1300/ J073v13n03_06

Januszewska, M. (2008): Proces dyfuzji innowacji w gospodarce turystycznej. In: A. Rapacz (ed.), Gospodarka a środowisko. Innowacyjność w gospodarce (pp. 101-113). Wrocław: Wydawnictwo Uniwersytetu Ekonomicznego we Wrocławiu.

Juvan, E., Dolnicar, S. (2016). Measuring environmentally sustainable tourist behaviour. Annals of Tourism Research, 59 (C), 30-44. https:// 10.1016/j.annals.2016.03.006

Kerr, J.H., de Kock, H. (2002). Aggression, violence, and the death of a Dutch soccer hooligan: A reversal theory explanation. Aggressive Behavior, 28 (1), 1-10. https://doi.org/10.1002/ab.90001

Larsen, J. (2008). De-exoticizing tourist travel: Everyday life and sociality on themove. Leisure Studies, 27 (1), 21-24. https://doi. org $/ 10.1080 / 02614360701198030$

Larsen, J., Urry, J., Axhausen, K. (2007). Networks and tourism: Mobile social life. Annals of Tourism Research, 34 (1), 244-262. https://doi.org/10.1016/j.annals.2006.08.002

Lash, S., Urry, J. (1994). Economies of signs and space. London: Sage Publications.

Li, T. (2015). A research of Chinese deviant behavior and its management. Economic Management, 37 (11), 113-123.

Łaźniewska, E. (2012). Turystyka w rozwoju lokalnym. Poznań: Uniwersytet Ekonomiczny w Poznaniu.

MacCannell, D. (1973). Staged authenticity: Arrangements of social space in tourist settings. American Journal of Sociology, 79, 589-603. http://www.jstor.org/stable/2776259. https://doi. org/10.1086/225585

MacCannell, D. (1976). The Tourist: A new theory of the leisure class. New York: Schocken Books. 
Maráková, V., Medvedová, M. (2016). Innovation in tourism destinations. Forum Scientiae Oeconomia, 4 (1), 33-43. https://wsb. edu.pl/container/FORUM\%20SCIENTIAE/forum $\% 202016 \% 20$ nr\%201/kwartalnik-1-2016-3.pdf

Marciszewska, B. (2010). Produkt turystyczny a ekonomia doświadczeń. Warsaw: Wydawnictwo C.H. Beck.

Maufakkir, O., Burns, P.M. (eds) (2012). Controversies in tourism. Oxfordshire: CABI.

Munt, I. (1994). The 'other' postmodern tourism: Culture, travel and the new middle class. Theory, Culture and Society, 11 (3), 101-123. https://doi.org/10.1177/026327694011003005

OECD, Eurostat (2005). Podręcznik Oslo. Zasady gromadzenia i interpretacji danych dotyczacych innowacji. Retrieved from: http://home.agh.edu.pl/ kkulak/lib/exe/fetch. php?media=user:konrad:vary:oslo-manual.pdf (20.10.2020).

Panasiuk, A. (2015). Miejsce turystyki kontrowersyjnej w strukturze rynku turystycznego. In: G. Godlewski. M. Zalech (ed.), Turystyka kontrowersyjna na wspótczesnym rynku podróży - formy, uwarunkowania, skutki (pp. 7-21). Biała Podlaska: AWF Józefa Piłsudskiego w Warszawie, Filia w Białej Podlaskiej.

Panasiuk, A. (2018). Kontrowersyjne obszary rynku turystycznego. Ekonomiczne Problemy Turystyki, 4 (36), 37-47. https://doi. org/10.18276/ept.2018.2.42-04

Park, D.-B., Yoon, Y.-S. (2009). Segmentation by motivation in rural tourism: A Korean case study. Tourism Management, 30 (1), 99-108. https://doi.org/10.1016/j.tourman.2008.03.011

Pearce, P., Lee U. (2005). Developing the travel career approach to tourist motivation. Journal of Travel Research, 43 (3), 226-237. https://doi.org/10.1177/0047287504272020

Pechlaner, H., Fischer, E., Hamman, E.M. (2006). Leadership and innovation processes-development of products and services based on core competencies. Journal of Quality Assurance in Hospitality and Tourism, 6 (3), 31-57. https://doi.org/10.1300/ J162v06n03_03

Pine, B.J., Gilmore, J.H. (1998). Welcome to the experience economy. Boston: Harvard Business Review. https://hbr.org/1998/07/ welcome-to-the-experience-economy

Porter, M.E. (1990). The competitive advantage of nations. New York: Free Press. https://doi.org/10.1007/978-1-349-11336-1

Ryan, C., Kinder, R.S. (1996). Tourism and sex tourism: Fulfilling similar needs? Tourism Management, 17 (7), 507-518. https:// doi.org/10.1016/S0261-5177(96)00068-4

Samimi, A.J., Sadeghi, Som., Sadeghi, Sor. (2011). Tourism and economic growth in developing countries: P-VAR approach. Middle-East Journal of Scientific Research, 10 (1), 28-32. http:// www.idosi.org/mejsr/mejsr10(1)11/5.pdf

Schumpeter, J.A. (1960). Teoria rozwoju gospodarczego. Warsaw: Państwowe Wydawnictwo Naukowe.

Scott, N., Laws, E., Prideaux, B. (eds) (2013). Safety and security in tourism: Recovery marketing after crises. New York: Routledge. https://doi.org/10.4324/9781315877372

Shields, R. (1992). Places on the margin: Alternative geographies of modernity. London: Routledge.
Stasiak, A. (2013). Tourist product in experience economy. Turyzm/Tourism, 23 (1), 28-35. https://doi.org/10.2478/ tour-2013-0012

Stasiak, A. (2015). Turystyka kontrowersyjna jako emanacja gospodarki doświadczeń. In: G. Godlewski, M. Zalech (eds), Turystyka kontrowersyjna na wspótczesnym rynku podró$\dot{z} y$ - formy, uwarunkowania, skutki (pp. 53-69). Biała Podlaska: AWF Józefa Piłsudskiego w Warszawie, Filia w Białej Podlaskiej.

Stebbins, R.A. (1996). Tolerable differences: Living with deviance. $2^{\text {nd }}$ edition. Toronto: Routledge.

Sztabiński, F., Żmijewska-Jędrzejczyk, T. (2012). Mixed mode survey design: problem efektu techniki. Przeglad Socjologiczny, 61 (1), 3-64.

Teitler-Regev, S., Shahrabani, S., Goziker, O. (2013). The effect of economic crises, epidemics and terrorism on tourism. International Journal of Business Tourism and Applied Sciences, 1 (1), 84-89. http://www.ijbts-journal.com/images/ column_1359163804/9\%20Sharon.pdf

Thirumaran, K. (2013). Managing graffiti at tourist attractions. In: Proceedings of the international conference on managing the Asian century (pp. 575-581). Singapore: Springer. https://doi. org/10.1007/978-981-4560-61-0_64

Turner, L., Ash, J. (1975). The golden hordes: International tourism and the pleasure periphery. London: Constable.

UNWTO (2019). International tourism higlights. Retrieved from: https://www.e-unwto.org/doi/pdf/10.18111/9789284421152 (5.05.2020).

Uriely, N. (2005). The tourist experience: Conceptual developments. Annals of Tourism Research, 32 (1), 199-216. https:// doi.org/10.1016/j.annals.2004.07.008

Uriely, N. (2010). 'Home' and 'away' in VFR tourism. Annals of Tourism Research, 37 (3), 854-857. https://doi.org/10.1016/j. annals.2010.02.006

Uriely, N., Belhassen, Y. (2005). Drugs and tourists' experiences. Journal of Travel Research, 43 (3), 238-246. https://doi. org/10.1177/0047287504272024

Uriely, N., Belhassen, Y. (2006). Drugs and risk-taking in tourism. Annals of Tourism Research, 33 (2), 339-359. https://doi. org/10.1016/j.annals.2005.10.009

Uriely, N., Ram, Y., Ayala, M.-P. (2011). Psychoanalytic sociology of deviant tourist behavior. Annals of Tourism Research, 38 (3), 1051-1069. https://doi.org/10.1016/j.annals.2011.01.014

Urry, J. (1990). The Tourist Gaze: Leisure and travel in contemporary societies. London: Sage Publications Ltd.

Wang, N. (2000). Tourism and modernity: A sociological analysis. New York: Emerald.

Weaver, D.B. (2006). Sustainable tourism: Theory and practice. London: Elsevier Butterworth-Heinemann.

Weiermair, K. (2004). Product improvement or innovation: What is the key to success in tourism? In: OECD innovation and growth in tourism (pp. 53-69). Paris: OECD Publishing. https:// www.oecd.org/cfe/tourism/34267947.pdf 